ИСТОРИЈСКИ ЧАСОПИС, књ. LXVIII (2019) стр. 415-429

THE HISTORICAL REVIEW, vol. LXVIII (2019) pp. 415-429

УДК: 94(497.11):305-055.2“1917“"

DOI: $10.34298 / \mathrm{IC} 1968415 \mathrm{M}$

\author{
Божица Б. МЛАДЕНОВИЋ ${ }^{*}$ \\ Универзитет у Нишу \\ Филозофски факултет \\ Департман за историју \\ Ниш
}

\title{
„ЉУБИЧИЦЕ, И ЈА БИХ ТЕ БРАЛА...”. „ЖЕНСКО ДРУШТВО” У ДНЕВНИКУ ТОШКА ВЛАХОВИЋА
}

Ancmpaкm: Драгоцене белешке, настале из пера Тошка Влаховића, студента филозофије, четничког војводе и команданта Крајинског одреда у Топличком устанку и покрету отпора, садрже податке о најважнијим догађајима од 31. јануара 1917, до погибије аутора 2. новембра исте године. Користећи дневник као вредан историјски извор који сведочи о времену када је написан, приказаћемо „женско друштво” у окупираној Краљевини Србији за време Великог рата. Кроз обраду три сегмента: однос жена према устаницима и борцима за слободу, према окупационој бугарској власти и њеним представницима и страдање жена за време окупације у Великом рату, покушаћемо да одговоримо на насловну тему.

Кључне речи: „Женско друштво”, Тошко Влаховић, дневник, Топлички устанак, герила, 1917. година.

Дневник Тошка Влаховића је огледало личности која га је писала, његовог виђења рата и ратног морала. ${ }^{1}$ Аутор дневника био је студент

*bozica.mladenovic@filfak.ni.ac.rs

** Рад је настао у оквиру истраживања на пројекту Историјско наслеђе Балканског полуострва кроз векове (од антике до савременог доба), који се реализује на Филозофском факултету у Нишу.

1 Дневник је постао плен бугарске војске после погибије Тошка Влаховића 2. новембра 1917. године у близини села Власова. Чува се у Централном државном архиву у Софији. (Централен държавен архив (ЦДА), Ф. 176 К, Министерство на външите работи и изповеданията (МВРИ) Опис (ОП.) 4, архивна диница (а.е.) 19 , лист (л.). 3-48, 50-109, 110-118. 
филозофије, руски и немачки ђак, паметан и скроман младић, патриота, лепо васпитан и образован. ${ }^{2}$ И у ратним недаћама остао је идеалиста и борац за слободу до погибије. Влаховић је био интелектуалац који је и у шуми, усред непријатељских потера, читао Огледе Томаса Бабингтона Маколија, ${ }^{3}$, „спој” борца и политичког комесара, човек до краја посвећен и одан ,заједничкој ствари”. После једног века, белешке у којима је аутор понудио реалну слику историјске стварности, постале су доступне истраживачима. ${ }^{4}$

У Влаховићевом дневнику, између осталог, наилазимо и на описе демографске катастрофе која је задесила српски народ у Великом рату. Окупирано српско друштво највећим делом чинило је женско становништво. Друга по бројности била су деца, док је мушкараца било у знатно мањем броју. Из пописа који је направила аустроугарска окупациона власт види се да су најбројнији били старији мушкарци, потом мушкарци млађих година (деца и дечаци). ${ }^{5}$ Међу побројанима су и мушкарци неспособни за рат свих животних доба и они који се у јесен 1915. године нису повукли преко Црне Горе и Албаније са већином српске војске. У историографији је већ устаљен термин „женско друштво”, који је први употребио академик Андреј Митровић. Овом фразом се лаконски објашњава демографска ситуација карактеристична за Велики рат и време које му је следило. Бројни мушкарци погинули су у борбама, други су ратовали на јужном фронту или су интернирани у логорима држава Централних сила (Бугарска и Аустроугарска). То је било неуобичајено

2 Тошко Влаховић (Трмање 1892 - Власово 1917). Матурирао на Цетињу 1911. Студирао је филозофију, као стипендиста црногорске владе, у Русији и Немачкој. Једну школску годину, 1911/12. био је на студијама на Универзитету у Петрограду, а две школске године, од 1912. до лета 1914, на Универзитету у Јени. У Првом светском рату био је добровољац у Првом батаљону Колашинске бригаде, до капитулације Црне Горе. У Топличком устанку административни помоћник Косте Миловановића Пећанца и командант Крајинског одреда. (Браћа Влаховић 1917, прир. М. Влаховић, Београд 1987, 17-18.)

3 Томас Бабингтон Маколи (1800-1859), британски историчар и виговски политичар. Његова најпознатија дела су: Макијавели, Фридрих Велики, Милтон, и Историја Енглеске. Меколијев приступ писању био је иновативан за његову епоху. Он је сјединио стил античких историчара (Тукидид, Тацит) и сазнајни, чињенични приступ 18. века који су примењивали његови претходници.

4 Тошко Влаховић, Уточишта ни код кога. Дневник из 1917. године, (у даљем тексту: Уточищта ни код кога) прир. Б. Младеновић, Нови Сад 2018.

5 Ortsverzeichnis für das von den k.u.k. Truppen besetzte Gebiet Serbiens. Zusammengestellt auf Grund der Ergebnisse der Volkszählung vom 10. Juli 1916. in Gegenüberstellung zu jenen der Volkszählung vom 31. Dezember 1910, Belgrad 1917. 
„„Бубичище, и ја бих те брала...”. „Женско друштво” у дневнику Тошка Влаховића

друштвено стање, када жене млађих и средњих година, биолошки оптимално способне за репродукцију, нису имале брачног партнера. ${ }^{6}$

У дневнику је Тошко Влаховић писао и о женама и девојкама. Карактеристично је да је употребљавао израз „женске”, који је тада био уобичајен у свакодневном говору. Изузетак је направио када је писао о неколико образованих жена и девојака, које су припадале грађанском слоју српског друштва. Када је време проводио са њима, у ретким приликама пре почетка устаничких борби, фебруара 1917. године, говорио је да је био ,у друштву образованих дама”.?

Место у коме је млађи Влаховић упознао „даме” било је село Бериље. На дановнику у Бериљу 14. фебруара налазили су се предводници покрета отпора - Коста Војиновић, Коста Пећанац, Јован Радовић... Њима су у посету дошле „многе даме, жене из Прокупља и околине”. Посебно је издвојио госпођу Ангелину Илић, учитељицу и националног радника, оснивача Кола српских сестара у Прокупљу. Њен супруг, народни посланик Илија Илић био је на фронту. Госпођа Илић је са својим пријатељицама дошла да пружи моралну подршку борцима за слободу. Влаховић није крио своје одушевљење: „Нигдје више женских образа нисмо нашли на окупу, те смо тај дан провели прилично пријатно у разговору и пјесми $[\ldots]^{\prime \prime} 9$

Други пут је Влаховић сусрео образоване жене и девојке у селу Коњарнику. Увече 17. фебруара су Војиновић, Пећанац, Радовић и Влаховић боравили у овом селу: „Велика маса очекиваше нас ту, нарочито женске, јер мушких, нарочито обвезника немаше много. Већим дијелом су на фронту. Женских нигдје није било толико на окупу као овдје." Поименично је издвојио госпођу Којовић, супругу капетана Љубомира Којовића, који је био официр у Другом пешадијском пуку „Књаз Михаило”, познатијем као Гвоздени пук, попадију, „госпођу попа Васа” и госпођицу Пилетић, „кћерку

6 Б. Младеновић, Рат и приватност: Велики рат, Приватни живот код Срба у двадесетом веку, Београд 2007, 771.

7 Уточиита ни код кога, 27.

8 Јован Радовић (Баре код Колашина 1891 - Сарајево 1918). Матурирао у Београду 1911, потом студирао у Лајпцигу. У устанку организациони помоћник у штабу Косте Миловановића Пећанца, потом командант Пиротског одреда. Учествовао у борбама за ослобођење Србије и Црне Горе у октобру 1918. године. (Браћа Влаховић 1917, 17.) Радовић, кога су припадници покрета отпора ословљавали са професор, био је близак пријатељ Тошка Влаховића. Више о Јовану Радовићу: М. Влаховић, Јован Радовић (1891-1918), Београд 1992.

9 Уточишта ни код кога, 24. 
Блажа Пилетића."10 Дружење са госпођама и госпођицом продужило се до зоре: „То вече смо пријатно провели и остали сједећи до испред зоре до кретања; нарочито смо се много смејали г.[осподину] Војиновићу кад је своје пјесме читао. Он и професор ријешише да приморају г[оспо]ђе и г[оспо]ђицу да нико не спава и збиља у томе и успјеше". ${ }^{11}$ Сутрадан су челни људи српског покрета отпора наставили дружење са дамама из Коњарника. Оне су по договору („обећању”), 18. фебруара дошле у село Горњи Дреновац. Како је записао Тошко, „дођоше око пола дана, те тако и тај остатак дана проведосмо у друштву образованих дама". ${ }^{12}$ Теме за разговор нису биле исцрпљене, али ово је био последњи сусрет младог четничког војводе са младим и образованим женама и девојком.

На страницама дневника аутор је, описујући свакодневицу, оставио драгоцене податке о српском друштву за време окупације у Великом рату. По његовим запажањима, последице рата и окупације имале су негативан утицај и произвеле су појаве које нису могле служити на част окупираном становништву. Овај историјски извор потврђује резултате ранијих истраживања да је то било располућено друштво, у коме је већински део становништва био непријатељски расположен према окупационој власти. Срби су били принуђени бруталном применом власти од стране окупатора да извршавају његове наредбе и поштују прописе. Због тога су односи између окупираних и окупатора углавном били конвенционални и сводили се у већини случајева само на обавезе. Већина Срба остала је хладна и без симпатија према новом режиму, изузимајући мали број оних који су учествовали у локалној власти и имали и необавезне односе са окупаторима. ${ }^{13}$ Тошко Влаховић је забележио да су жене и девојке пружале помоћ и подршку учесницима покрета отпора и устаницима, али и да су постојале „женске” које су сарађивале са бугарском окупационом влашћу. Оне су шпијунирале и пријављивале Србе, своје комшије и сељане, због разних ,прекршаја". ${ }^{14}$

${ }^{10}$ Исто, 27. Из поштовања према госпођици, Влаховић није написао њено име.

${ }^{11}$ Исто, 27.

12 Уточишта ни код кога, 27.

${ }_{13}$ Б. Младеновић, Град у аустроугарској окупаиионој зони 1916-1918, Београд 2000,59 .

${ }^{14}$ Тошко Влаховић је искључиво боравио на територији која је била под окупацијом бугарске војске. То је подручје Војно-инспекцијске области Морава, са седиштем у Нишу. 


\section{Сараднице четника}

У окупираној Краљевини Србији владао је терор и бруталност, пљачка и безакоње. Иако су биле пљачкане, малтретиране, оптерећене пољским и кућним пословима, већина жена је веровала да је окупација само привремено зло. У „женском друштву” је владао оптимизам по питању коначног исхода рата. Жене су и пре устанка пружале помоћ четницима, дајући им храну и преобуку. Већина жена и девојака је давала моралну и материјалну подршку четницима и прихватала их као легитимне представнике Краљевине Србије. Осим жеље за обнављањем независне српске државе и мржње према окупатору, било је присутно још различитих мотива за пружање помоћи и подршке борцима за слободу. У друштву које је доживело „демографску катастрофу”, разумљива је оданост и лојалност припадница нежнијег пола према припадницима покрета отпора, изузимајући је потпуно из политичког контекста. ${ }^{15}$

Жене су на различите начине помагале четницима у устанку али и у периоду који је уследио по завршетку устаничких борби. Док је трајала борба против окупационе власти, жене и девојке су се нашле у улогама бораца, курира, болничарки... По окончању устанка, неке од њих су наставиле да четују у борбеном крилу српске гериле и да обављају курирске послове. Друге су пак пружале драгоцену помоћ у снабдевању животним намирницама, скривању и неговању рањених бораца.

\section{Боричи}

У постојећој литератури је написано да су се жене и девојке бориле у Ибарско-копаоничком одреду, Јабланичком и Централном одреду. У Јабланичком одреду којим је командовао четнички војвода и капетан црногорске војске Милинко Влаховић, борила се Даница, девојка из села Стубла. У борбу је отишла заједно са вереником Милошем Ђуровићем. ${ }^{16}$ По престанку устаничких борби Даница је наставила да четује са својим вереником. У дневнику се налазе подаци о даљим Даничиним активностима. Одељење Милоша Ђуровића боравило је на планини Кукавици. Изгледа да је у данима непосредно по пропасти устанка Ђуровић почео неки свој „рат”. Он није „ухватио” везу са Милинком Влаховићем, који му је био претпостављени, него је одлучио да створи

${ }^{15}$ Б. Младеновић, Жена у Топличком устанку 1917( у даљем тексту: Жена), Београд 1996, 63.

${ }^{16}$ Исто, 71. 
сопствену организацију. О овоме је Тошку Влаховићу 12. априла ${ }^{17}$ вест донео четник Драгутин Митровић, који је био борац у Ђуровићевом одељењу. ${ }^{18}$ Митровић је испричао да је наредник Ђуровић „произвео Даницу у чин наредника, а такође и тројицу из свог одељења, од којих је један био кувар". Новоизабрани наредници су потом изабрали Милоша Ђуровића за војводу. Остали борци били су врло незадовољни новим стањем у одељењу. Ђуровић је узурпирао власт да би задовољавао своје и Даничине потребе. ${ }^{19}$ На основу расположивих извора првог реда не можемо ни потврдити ни негирати ову причу. Јасно је да су Милош Ђуровић и Даница наставили да четују, али податке о томе да нису поштовали строга правила за припаднике покрета отпора, чија је суштина била склад између речи и дела, нисмо пронашли у другим историјским изворима.

\section{Курири}

Жене и девојке су обављале „курирску службу” на слободној територији док су трајале борбе. ${ }^{20}$ Такође су припаднице нежнијег пола наставиле са овим послом и у наставку активности борбеног крила покрета отпора. Белешке Тошка Влаховића то потврђују. Наиме, 11. маја је стигла патрола коју је послао у вишедневни обилазак и извиђања терена, са задатком да сазнају место боравка Косте Пећанца и да „се увере да ли је постојало неко писмо од њега за мене као што ме тог дана извести једна жена из Пасјаче". ${ }^{21}$ Четнички војвода Пећанац је наставио стару праксу да поверљиве жене носе његова писма и наредбе другим командантима и четовођама.

\section{Подрика и помоћ}

Подршка и помоћ коју су четници добијали од жена у времену када за њих нигде није било уточишта, била је посебно драгоцена. Влаховићева

${ }^{17}$ Сви датуми у основном тексту су по новом календару, ако није другачије наглашено.

18 Уточишта ни код кога, 44-45.

19 Митровић је још испричао да, ,утиче на њега [Ђуровића] једино Даница, и да се једино о њој стара. Све што дође од хране узима за себе и Даницу, а за комору употребио је двојицу четника, којима је пушке одузео, а бисаге притоварио." (Уточишта ни код кога, 45.)

${ }^{20}$ Б. Младеновић, Жене, 29-30.

${ }^{21}$ Уточишта ни код кога, 53-54. 
сведочанства су драгоцена због реалности у опису. Он је записивао примере који га нису остављали равнодушним. Студент филозофије је посебно био дирнут размишљањем и понашањем девојке Милеве Стевановић. Он је 21. августа 1917. написао: „Свануло беше када наиђем кроз село Чукуровце. Распитам се за Бугаре. [...] У овим обавештењима нарочито запазисмо девојку Милеву Стевановићеву која нам слободно, отворено и смело каза све што знаваше". 22 Такође је јаке емоције младог четничког војводе изазвао дочек приређен њему и његовим саборцима 18. јуна у селу Петровцу: „Вечеру добисмо из села Петровца које нас са таквим одушевљењем дочека као да им заиста тог тренутка доносимо слободу или као да не схватаху каква је опасност имати везе са комитама. Нарочито се истицаху женске својим слободоумним и отвореним понашањем, што је заиста служило на част потомцима чувених Дрекаловића". ${ }^{23}$

Мајке бораца су такође помагале. У дневнику је записано више примера, али смо издвојили два. Мајка четника Алексе Булатовића, „сирота без куће и кућишта” донела је два хлеба саборцима свога сина. ${ }^{24}$ На Ускрс, 15. априла 1917. године ручак је спремила мајка четника Милорада Перовића и донела га борцима у Зоровачкој шуми. ${ }^{25}$

\section{Сараднице окупатора}

Срби и Српкиње су углавном били одани борцима покрета отпора у јесен 1916. и зиму 1917. Неповољне околности: страдање у устанку и по његовом сламању, утицале су на повећање броја становника који су сарађивали са окупатором. Они су учествовали у потерама заједно са бугарским и аустроугарским трупама, пријављивали људе који су на било који начин помагали организацију покрета отпора, српске војнике који се нису повукли преко Албаније... Из дневника се види да су сељани ревносно прихватили захтев окупационих власти да чувају села од уласка четника и обавештавају их о кретању истих. Резултат те агилности била су свакодневна страдања четника по слому устанка, када су били гоњени на сваком кораку.

Командант Крајинског одреда приметио је „опадање морала”. Посебно је у пролеће четврте ратне године дошло до промене понашања

${ }^{22}$ Исто, 129-130.

${ }_{23}$ Исто, 71.

${ }^{24}$ Исто, 42.

${ }_{25}$ Уточишта ни код кога, 46. 
становништва на територији којом је прошла казнена експедиција трупа Централних сила. „Шпијунажа се све више ширила, нарочито од стране жена, чији је морал био на најнижем ступњу”, забележио је млађи Влаховић. ${ }^{26}$ Једна жена ( ,снаха деда Стојка”) је, још док су трајале устаничке борбе, пријавила бугарској војсци да се у кући у селу Клајићу налазе четници. Бугарска артиљерија је у току дана више пута гађала кућу. Када су се борци Крајинског одреда увече вратили са положаја „код куће нема никог, свесни су били дела које су учинили". ${ }^{27}$ На Видовдан четврте ратне године мештани Широких Њива доживели су својеврсну тортуру „парењем и пљачкањем” због оптужбе неке жене из села. ${ }^{28}$

Две жене су своју помоћ и сарадњу са припадницима окупационих сила платиле главом. Обе су животни пут окончале у мају 1917. године. Једна се звала Милуника и живела је у селу Обилићу. Њу су мештани тужили Влаховићу, који је послао патролу да је доведу „да је саслушам за неке ствари". Милуника је, по оптужбама, пријављивала Бугарима своје сељане, сакрила 15 бугарских војника када су били поражени у Житном Потоку за време устанка. Такође су је оптужили ,да живи с кметом и да је са њим имала једно ванбрачно дете иако има свог мужа.” Четници који су били у патроли говорили су бугарски. Милуника им је отворила врата, „,али када виђе ко је пође са њима до врата, гурне последњег четника низа степенице, затвори за њима врата, па лати секиру да се брани од Срба. Четници поломе прозоре и сасеку је насред собе и ту оставе мртву”. ${ }^{29}$

Друга жена, Роска из Драговца, осуђена је на смрт зато што је била оптужена да је доушник и љубавница бугарским војницима. Патрола која је извршавала задатак обавестила је команданта да је убила ,једну покварену жену [...] Роску”. Роска је убијена ,а два Бугарина која су код ње стално била остадоше у Драговцу плачући за својом швалерком и дрхтећи од страха да и њих може то постићи". ${ }^{30}$ Њено убиство требало је да послужи као опомена другим женама које су се слично понашале.

Крајински одред је у лето 1917. године преживљавао тешке дане. Сељани су чували села и пријављивали кретање четника, а судећи по подацима из овог историјског извора, и жене су „драговољно” ступале у интимне односе са бугарским војницима. Белешка настала 14. јула сведочи о томе: „Кад смо улазили у село сеоска стража у јачини 8 људи дочека

\footnotetext{
${ }^{26}$ Исто, 55.

${ }^{27}$ Исто, 34.

${ }^{28}$ Исто, 83.

${ }^{29}$ Уточишта ни код кога, 52.

${ }^{30}$ Исто, 55.
} 
нас прописно на улазу наоружани секирама и батинама. Кад их запитах против кога носе секире рекоше ми да смо им наредили да убију комите њиме чим им виде (држаху нас за Бугаре премда ми сви имасмо српско одело и чак српски говорасмо). Тако исто сељаци одмах помислише да су Бугари па се пограбише ко ће веће услуге да им учини али чим видеше да смо Срби одједанпут почеше молити да их не убијамо, да им женске не дирамо, премда у село нико од четника не беше отишао, него бесмо сви на окупу и један мало слободнији додаде: „Зар се плашите толико од Срба који ево готово после две године први пут у наше село долазе, а стидите се признати да у селу има десет женских које ће, да простите, скоро родити што су драговољно имале посла с Бугарима."з1

У лето (23. јул) једна жена се уплашила од „наоружаних људи”. 32 Влаховић није написао да ли су се борци из његовог одреда преобукли у бугарско војничко одело или су носили српско, па је нејасно од кога је заправо „женска” побегла. Два дана раније, Влаховић је, обучен у бугарско војничко одело, кренуо са патролом путем од Доње ка Горњој Каменици: „[...] Успут наиђосмо на многе раднике. Не бесмо никоме досадили, нарочито женским. Две женске кад нас угледаше с брдашца, запеваше: „Љубичице, и ја бих те брала, немам драгог коме бих те дала.” То су певале све док смо ми премакли за брдо." ${ }^{33}$ Песма девојачка била је упућена бугарским војницима, јер оне нису могле знати да су то у ствари српски борци за слободу. Отуда је ваљда и иронична забелешка да у бугарском оделу нису досадили, нарочито женама.

Одред Тошка Влаховића се стално сусретао са проблемом набавке хране. Командант је уредно плаћао за животне намирнице које су биле потребне за исхрану. Пролеће, лето и јесен Влаховић је запамтио по сталном гладовању. Било је мало људи који су смели да продају храну четницима. На Петровдан је Тошко записао: „Закуцамо на врата од једне мале куће и отвори нам једна баба. Пошто је њена кућа била мала а она сама без парчета хлеба наредимо јој да нас одведе до неке повише куће где ће она јавити да нам отворе. Тако и учини, пођемо до најближе куће на неких 50 корака и баба се јави суседима објаснивши им ко тражи да им се отвори. Уместо да отворе врата жене потрчаше на прозор па чак с другог и трећег спрата почеше викати по целом селу". 34

\footnotetext{
${ }^{31}$ Исто, 97.

${ }^{32}$ Исто, 103.

33 Уточишта ни код кога, 103.

${ }^{34}$ Исто, 95.
} 
Викање, запомагање, кукање, закључана улазна врата кућа - тако су се жене „браниле” од четника, који су углавном ноћу долазили у села да купе хлеб и понеку животну намирницу. Лето је прошло са мало хране, уз коришћење дивљег воћа да би се заварала глад. И у јесен су прилике биле сличне. Некада су добијали комад „овсенице промешане са камењем”, 35 заправо хлеб који су јели становници села. Оскудица и немаштина је била присутна у сваком селу и у већини домаћинстава.

Женска „ларма” је 25. септембра погодила у срце младог четничког војводу: „Јавимо се само код једне куће у Гајтану. Читава дрека и ларма од неких женских. Коре нас предајом осталих четника па се боје да ћемо и ми тако учинити. Казаше да су ту ноћ јавили Бугарима за наш долазак те да морају и они вечерас. Псовању краја нема и с оним ко нас посла овуда и где смо чули да има комитске државе. За храну не даду ништа". ${ }^{36}$ Село Гајтан је било једно од насеља које је највише пострадало у казненој експедицији бугарске војске 21. и 22. марта 1917. године. Влаховић је, вероватно имајући то на уму, разумео овакав поступак жена и са борцима отишао гладан из села.

\section{Страдање жена}

Одребде међународног позитивног права штитиле су и посебно третирале цивилно становништво у рату. ${ }^{37}$ То је бугарска окупациона власт потпуно ниподаштавала. Влаховићеве белешке сведоче о великом страдању цивилног становништва у казненој експедицији трупа Централних сила и о бруталним казнама које су примењиване према женској популацији. ${ }^{38}$

\footnotetext{
${ }^{35}$ Исто, 104.

${ }^{36}$ Исто, 143.

${ }^{37}$ М. Милојевић, Повреде Хашких и Женевских конвениија у Србији, Зборник радова Историјског института Србија 1917. Године, Београд 1988, 21-35.

38 Аутор дневника је уредно и редовно записивао дневне догађаје и због тога да би за генерације које долазе оставио податке о суровости окупационог режима. Посебно о мукама, патњама и страдању девојака и жена.
} 
У дневнику се налазе подаци о убиствима ${ }^{39}$ и тучи жена. ${ }^{40}$ Поред бугарских војника и комита, Влаховић је као учесника у једном злочину навео и Србина, који је био кмет. ${ }^{41}$ Жене и девојке биле су жртве сексуалног злостављања. Подаци које налазимо сведоче о девијантним појавама које су се јављале у организацији покрета отпора. Наиме, већ је забележено у историографији, ${ }^{42}$ а сада је поново потврђено да су Српкиње силовали и четници. Овога пута четници под командом Тодора Митића Слишанског. Дневник настао пре више од једног века неумољиво оптужује: „Пет четника Тоше Слишанчета дошли у то село (Бублица) и силовали једну честиту Српкињу. Ти ниткови и данас живе називајући се „српским четницима”. ${ }^{43}$ Осим овог злочина, Влаховић је забележио: „Жале се кметови да се четници Тоше Слишанског крећу сувише јавно, да су сваког дана по селима, нарочито да јуре женске, због чега и долази војска, па су последњих дана многи ухапшени". ${ }^{4}$

Жене и девојке биле су сексуално злостављане од припадника окупационе власти. Овакво понашање војника регуларних бугарских трупа забележено је од почетка окупације Краљевине Србије, када су се силовања дешавала спорадично. После угушења великог народног устанка појава је постала масовна. ${ }^{45}$ Четници су, када је стицај околности то омогућавао, покушавали да заштите жене и девојке од напаствовања.

39 Бугарски војници стрељали су Магдалену Николић, супругу народног посланика Гаврила Николића. Тошко је 6. априла сазнао за њену смрт. „[...] казиваху и страхоте и недела почињена у суседним селима, као и у Лебанима, где су чак и болничарку гђу Магу која је лечила и њихове рањенике стрељали.“ (Уточишта ни ког кога, 41.) Међу сурово убијенима била је и мајка четовође Милорада Перовића. Она је стално помагала свом сину и његовм борцима. Више пута им је доносила ручак и давала животне намирнице. Убијена је неколико дана после Ускрса. (Уточишта ни код кога, 47-48.)

40 За 5. фебруар у бележници стоји да су Бугари жестоко казнили жену коју су ухватили да носи ручак четницима. Ударили су јој 50 батина, а она 'опет не признала". (Уточишта ни код кога, 21).

${ }^{41}$ Описујући смрт мајке Милорада Перовића, Влаховић је записао да је у њеној ликвидацији помагао кмет Аксентије Аранђеловић, који се хвалио да је „дошао с комитама [бугарским] до куће Милорада Перовића у Зоровац, где је његова мајка заклана [...]“. (Уточишта ни код кога, 47-48.)

42 Б. Младеновић, Комитски преки суд, Зборник радова Историјског института Србија 1917. године, Београд 1988, 81-94.

43 Уточишт ни код кога, 133.

${ }^{44}$ Исто, 133.

45 Б. Младеновић, Жена, 91-96. 
Последњег дана јуна 1917. Тошко је записао да га је вођа патроле Радосав Поповић обавестио да су се сукобили са бугарским војницима код села Новог Момчилова и Границе четири дана раније: „Неколико коњаника силовало сестру и снаху четника А. Лазовића који се с том патролом баш ту налазио. Они напали и отворила се борба. Бугарима дошли у помоћ коњаници из Обилића, јер је ту логоровао један ескадрон”. У сукобу је погинуо један и рањен један бугарски војник. Командант одреда је подржао своје борце из патроле: „У овом случају морао би сваки да се освети овим нитковима, да виде да још неког има од кога треба да се боје. Што ми више ћутимо, они више нереда праве". ${ }^{46}$

Официри бугарске војске, судећи по овом историјском извору, нису се трудили да обуздају своје војнике. Напротив! Наилазимо на податке да су војници силовали девојчице од десет до дванаест година. ${ }^{47}$ Официри су понекад својим понашањем давали погрешан пример подређенима. Командант бугарске јединице која је била стационирана на Славничкој Чуки био је „и сувише безобразан човек, нарочито у опхођењу са женскима, шиљао војнике те су му доводили све најљепше женске из околине да силује од којих су многе од таквог зулума и у шуму побегле". 48

Бугарска војска и њихове паравојне формације апсолутно нису поштовале одребде међународног права које су се тицале заштите приватне својине. О томе је потресна сведочанства оставио Тошко Влаховић. Он је, као савременик силне пљачке и уништавања имовине у казненој експедицији и времену после ње, оставио ове редове: „Желели су и хтели [Бугари] да окупиране крајеве опусте скроз и скроз. Са пљачком никако не престајаху. Још увек свлачаху бабе да им траже паре, одузимаху из куће све па опет продаваху. Претресаху жене које иду за Лесковац па им одузимаху и последње парче хлеба из торбе.”49 На Ђурђевдан је приметио: „Бугари су много претили са претресом шума, али су мало то извршавали, него се више муваху по селима, да би што појели и опљачкали, пошто беху гладни као пси, јер је немогуће живети с 450 грама сува хлеба и другом војнику а камоли Бугарину који у једном селу (наравно српском) 12 пута ручава." 50 Десетак дана касније бугарски војници су спалили два села, Малу и Велику Црквицу. ${ }^{51}$ У пожару је сагорео вишегодишњи труд сељана и они су постали бескућници без игде ичега.

\footnotetext{
46 Уточишта ни код кога, 84.

${ }^{47}$ Исто, 56.

${ }^{48}$ Исто, 53.

${ }^{49}$ Исто, 50.

${ }^{50}$ Исто, 53.

${ }^{51}$ Исто, 56.
} 
Две недеље пред погибију Тошко Влаховић је сазнао о неком „Протесту” од стране српске владе или владе неких неутралних држава (вероватно Швајцарске, која је била седиште Црвеног крста), упереном против „бугарских поступака и недела по Србији”. Бугарска окупациона власт је била принуђена да одговори на ове оптужбе и због тога су „приморали све жене у Прокупљу и гђу Илије Илића” да изјаве како је њима „веома добро с Бугарима и да су оне више но задовољне оваквим начином владавине”. Студент филозофије је прокоментарисао: „Лепо оправдање!!!”52

Дневник Тошка Влаховића настајао је у тешком времену, када је императив био преживети. Живот се претворио у непрекидну и немилосрдну борбу за очување голе егзистенције. У тој борби се на моменте заборављало на „више циљеве”, патриотизам, отаџбину... Управо то чини овај историјски извор драгоценим. Дневник је истинит, реалистичан, сликовит. Богатством примера којима је Тошко Влаховић илустровао „одступања од правила” приказао је тамне и светле стране живота „женског друштва” за време окупације.

52 Уточишта ни код кога, 153. 


\section{ЛИСТА РЕФЕРЕНЦИ - LIST OF REFERENCES}

\section{Архиви - Archives}

Централни државни архив у Софији (Централен държавен архив (ЦДА) [Centralni državni arhiv u Sofiji]

- Министарство спољних послова и вере (Министерство на външите работи и изповеданията (МВРИ)) [Ministarstvo spoljnih poslova i vere]

Војни архив [Vojni arhiv]

- Пописник 7 [Popisnik 7]

\section{Извори - Primary Sources}

Ortsverzeichnis für das von den k.u.k. Truppen besetzte Gebiet Serbiens. Zusammengestellt auf Grund der Ergebnisse der Volkszählung vom 10. Juli 1916.in Gegenüberstellung zu jenen der Volkszählung vom 31. Dezember 1910, Belgrad 1917.

Браћа Влаховић 1917, прир. М. Влаховић, Београд 1987. [Braća Vlahović 1917, prir. М. Vlahović, Beograd 1987]

Влаховић Т., Уточишта ни код кога. Дневник из 1917. године, прир. Б. Младеновић, Нови Сад 2018. [Vlahović, T., Utočišta ni kod koga. Dnevnik iz 1917. godine, prir. B. Mladenović, Novi Sad 2018]

Дневник Косте Миловановића Пећанца од 1916. до 1918. године, прир. Б. Младеновић, Београд 1998. [Dnevnik Koste Milovanovića Pećanca od 1916. do 1918.godine, prir. B. Mladenović, Beograd 1998]

\section{Литература - Secondary Works}

Влаховић М., Јован Радовић (1891-1918), Београд 1992. [Vlahović, M., Jovan Radović (1892-1918), Beograd 1992]

Милојевић М., Повреде Хашких и Женевских конвениија у Србији, Зборник радова Историјског института Србија 1917. године, Београд 1988, 21-35. [Milojević M., Povrede Haških i Ženevskih konvencija u Srbiji, Zbornik radova Istorijskog instituta Srbija 1917. godine, Beograd 1988, 21-35]

Митровић А., Устаничке борбе у Србији 1916-1918, Београд 2017². [Mitrović A., Ustaničke borbe u Srbiji 1916-1918, Beograd 2017²]

Младеновић Б., Град у аустроугарској окупационој зони 1916-1918, Београд 2000. [Mladenović B., Grad u austrougarskoj okupacionoj zoni 1916-1918, Beograd 2000]

Младеновић, Б., Комитски преки суд, Зборник радова Историјског института Србија 1917. године, Београд 1988, 81-94. [Mladenović, B., Komitski preki sud, Zbornik radova Istorijskog instituta Srbija 1917. godine, Beograd 1988, 81-94]

Младеновић Б., Рат и приватност: Велики рат, Приватни живот код Срба у двадесетом веку, Београд 2007, 771. [Mladenović, B., Rat i privatnost: Veliki rat, Privatni život kod Srba u dvadesetom veku, Beograd 2007, 771] 


\section{Božica B. Mladenović}

\section{"LJUBIČICE, I JA BIH TE BRALA ...". "Women's Society" in the diary of Toško Vlahović}

\section{Summary}

Toško Vlahović was a student of philosophy at the universities of St. Petersburg and Jena, the Chetnik duke and the commander of the detachment of Krajina in the Serbian resistance movement and Toplica uprising. In his war diary, he recorded impressions of the female part of the population of the Kingdom of Serbia during the occupation in the Great War (1915-1918). For members of the tenderer sex, girls and women, Vojvoda Vlahović used the term "ženske" which was then used in everyday life.

The occupied Serbian society, which was to a certain extent divided, is presented realistically. Women and girls provided help and support to participants in the resistance movement and rebels, but there was also a small number of "chicks" who collaborated with the Bulgarian occupying authorities. This cooperation was reflected in the informative activities, i.e. reporting of compatriots for various "violations". Vlahović witnessed the massive suffering of the civilian population during the criminal expedition of the troops of the Central Powers, which followed the breakup of the uprising movement. In the diary he recorded the pain and suffering of girls, women (younger, middleaged, and elderly). Women were victims of abuse of Bulgarian soldiers and komitadji. But, sometimes, members of the Serbian resistance movement were also abusers. Women were raped, beaten, mistreated, sometimes killed.

Toško Vlahović's notebooks were written in difficult times, when the imperative was to survive. Life turned into a continuous and merciless struggle for the preservation of bare existence. In this fight, at times, the "goals", "patriotism", "the fatherland" were forgotten... This makes this historical source valuable. The diary is accurate, realistic, picturesque. The author, using the richness of the examples of the "deviations from the rule", illustratively presents the dark and bright side of the life of the "Women's Society" during the occupation.

Keywords: "Women's Society", Toško Vlahović, diary, Toplica uprising, resistance movement, 1917.

Чланак примљен: 29. 03. 2019.

Чланак коначно прихваћен за објављивање: 16. 09. 2019. 